\title{
High Concentrations of Transuranics and Natural Radioactive Elements in the Branchial Hearts of the Cephalopod Octopus vulgaris
}

\author{
J.-C. Guary ${ }^{1}$, J. J. W. Higgo ${ }^{2}$, R. D. Cherry ${ }^{1 *}$ and M. Heyraud ${ }^{1}$ \\ ${ }^{1}$ International Laboratory of Marine Radioactivity, Musée Océanographique, Monaco \\ ${ }^{2}$ Physics Department, University of Cape Town, Rondebosch, C. P., South Africa
}

\begin{abstract}
Data are reported which show elevated levels of plutonium and americium in the branchial hearts of the common cephalopod Octopus vulgaris. These levels were verified in both a laboratory experiment and in environmental samples. At the same time data for certain naturally-occurring radioactive isotopes of thorium, polonium and lead are given for comparison. Attention is directed to the potential of these small organs as monitors of transuranics and, probably, certain other elements in the marine environment.
\end{abstract}

The behaviour of transuranic elements in marine organisms is currently the subject of detailed study. Development of the nuclear industry will require that monitoring of plutonium, in particular, be continued in marine samples, and the identification of organisms, or organs thereof, which consistently accumulate transuranics to elevated levels is a matter of importance. Investigations are usually of two types: either a laboratory investigation is carried out, in which animals are exposed to sea water and/or food labelled with an appropriate radioactive isotope (Vilquin et al., 1975; Guary and Fowler, 1977; Fowler and Guary, 1977), or measurements are made of the transuranic elements at the very low levels at which they are found in environmental samples (Pillai et al., 1964; Noshkin, 1972; Higgo et al., 1977). The former are less tedious, but their interpretation is frequently ambiguous because it is very difficult to reproduce exactly in the laboratory such factors as the physico-chemical form of the element and the partitioning of its mode of uptake into the animal via the alternative routes of food and water.

We report here the results of an investigation in which both approaches were used. Unambiguous confirmation was obtained of elevated levels of plutonium and americium in the branchial hearts of the common octopus; also reported are levels of certain naturally-

\footnotetext{
- On leave from the Physics Department, University of Cape Town
}

occurring radioactive isotopes of thorium, polonium and lead in the same organs. We suggest that these small organs have considerable potential as monitors of transuranics and, probably, other elements in the environment.

Four individuals of the molluscan cephalopod Octopus vulgaris, ranging in wet weight from 80 to 140 $\mathrm{g}$, were caught off Monaco. They were placed in filtered and aerated sea water maintained at $13^{\circ} \pm 1 \mathrm{C}^{\circ}$; the sea water was spiked with ${ }^{237} \mathrm{Pu}$ adjusted to the +4 state (Fowler et al., 1975) at $0.7 \mathrm{kBq}(20 \mathrm{nCi}) \mathrm{l}^{-1}$ for two of the cephalopods, and with ${ }^{241} \mathrm{Am}$ (assumed to be in the +3 state) at $1 \mathrm{kBq}(30 \mathrm{nCi}) \mathrm{l}^{-1}$ for the other two. Throughout a 15 -d period the activity of the test animals was monitored regularly by gamma-spectrometry using a 3 " NaI (Tl) crystal; at the end of this period the cephalopods were dissected and the concentrations of the nuclides in the various organs were measured. Details of the uptake phase, the many organs involved, etc., will be given elsewhere; for our present purposes, the data given in Table 1 are of primary importance. They highlight the situation in the branchial hearts vis-à-vis the hepatopancreas; it is well-known that the latter organ accumulates many elements effectively. The high percentages of both nuclides in the branchial hearts, which constitute a mere $0.3 \%$ by weight of the whole animal, are immediately apparent, as are the high concentration factors with respect to the labelled sea water. We next performed an elimination experiment. Four further Octopus vulgaris (300 to $400 \mathrm{~g}$ wet weight each) were placed in ${ }^{237} \mathrm{Pu}$ and ${ }^{241} \mathrm{Am}$ labelled sea water for $10 \mathrm{~d}$, under the same conditions as previously. Each individual was then transferred to flowing (unlabelled) sea water, and was fed daily with crabs and gamma-counted regularly. For both nuclides the loss curve showed a three component loss. The first component (representing desorption) was very rapid and contained about $24 \%$ of the $\mathrm{Pu}$ and $\mathrm{Am}$; the 
Table 1. Octopus vulgaris. Concentration factors with respect to sea water (C.F.) and distribution (\%) of ${ }^{237} \mathrm{Pu}$ and ${ }^{241} \mathrm{Am}$ after a 15-d exposure to labelled sea water Two animals were dissected for each radionuclide and their organs grouped for analysis. Concentrations of the elements in sea water were: $0.7 \mathrm{kBq} \mathrm{l} l^{-1}$ for ${ }^{237} \mathrm{Pu}_{1} 1 \mathrm{kBq} \mathrm{l}{ }^{-1}$ for ${ }^{241} \mathrm{Am}$

\begin{tabular}{|c|c|c|c|c|c|}
\hline Sample & $\begin{array}{c}\% \text { of total-animal } \\
\text { wet weight }\end{array}$ & C.F. & $\begin{array}{l}{ }^{237} \mathrm{Pu} \\
\% \text { of total body burden }\end{array}$ & C.F. & $\begin{array}{l}{ }^{241} \mathrm{Am} \\
\% \text { of total body burden }\end{array}$ \\
\hline Branchial hearts & 0.3 & 9300 & 40.6 & 7100 & 72.8 \\
\hline Hepatopancreas & 2.9 & 50 & 2.2 & 20 & 1.3 \\
\hline Remainder & 96.8 & 45 & 57.2 & 10 & 25.9 \\
\hline Whole animal & 100.0 & 75 & 100.0 & 40 & 100.0 \\
\hline
\end{tabular}

second and third components had biological half-lives of about 1.8 and $560 \mathrm{~d}$ and contained about $30 \%$ and $46 \%$ of the elements respectively. Differences between $\mathrm{Am}$ and $\mathrm{Pu}$ in the loss kinetics were minimal. After $70 \mathrm{~d}$ of loss the cephalopods were dissected and the nuclide concentrations measured. At this stage the branchial hearts were found to contain no less than 88 $\%$ of the ${ }^{237} \mathrm{Pu}$ and $99 \%$ of the ${ }^{241} \mathrm{Am}$ in the whole animals. These high percentages reflect the very much slower loss of the elements from these organs than from the other organs and tissues of the cephalopod.

Our attention having been thus directed to the branchial hearts, we measured ${ }^{239+240} \mathrm{Pu}$ and ${ }^{241} \mathrm{Am}$ at environmental levels in further Octopus vulgaris specimens. Measurements of the radionuclides ${ }^{232} \mathrm{Th}$, ${ }^{230} \mathrm{Th},{ }^{228} \mathrm{Th},{ }^{210} \mathrm{Po}$ and ${ }^{210} \mathrm{~Pb}$ were also made. Standard chemical extraction techniques were used (Millard, 1963; Ku, 1965; Flynn, 1968; Wong, 1971), followed by alpha-spectrometry with surface barrier detectors for Am, Pu and Th and by alpha-counting with $\mathrm{ZnS}$ (Ag) phosphors (Hallden and Harley, 1960) for ${ }^{210} \mathrm{Po}$ and
${ }^{210} \mathrm{~Pb}$. The data are summarized in Table 2. Several features are apparent: (i) High levels of ${ }^{24 \mathrm{t}} \mathrm{Am}$ and ${ }^{237} \mathrm{Pu}$ in the branchial hearts are confirmed. (ii) Concentration factors in the branchial hearts with respect to sea water are close to those found in the laboratory experiment. (iii) Concentrations of the other three elements in the branchial hearts are also high, and concentration factors are close to $10^{4}$ for all five elements, despite their very different chemical properties. (iv) Concentrations of ${ }^{210} \mathrm{Po}$, and to a lesser extent ${ }^{210} \mathrm{~Pb}$, are high in the hepatopancreas, as has been found previously (Cherry and Shannon, 1974; Heyraud and Cherry, 1979). Note that ${ }^{241} \mathrm{Am},{ }^{239+240} \mathrm{Pu}$ and ${ }^{232} \mathrm{Th}$ are, by contrast, concentrated to a much smaller extent in this organ than in the branchial hearts. (v) The percentages of ${ }^{241} \mathrm{Am}$ and ${ }^{239+240} \mathrm{Pu}$ in the hepatopancreas and in the branchial hearts can be calculated. They differ from those found in the laboratory experiment, and these differences probably reflect the relative importance of the food and water uptake routes.

Octopus vulgaris is a littoral species common in

Table 2. Octopus vulgaris. Concentrations of ${ }^{241} \mathrm{Am},{ }^{239+240} \mathrm{Pu},{ }^{232} \mathrm{Th},{ }^{210} \mathrm{~Pb}$ and ${ }^{210} \mathrm{Po}$ in cephalopods collected in the littoral zone off Monaco. For ${ }^{239+240} \mathrm{Pu}$, means are of 3 samples comprising 4, 5 and 54 individuals respectively; for ${ }^{241}$ Am, of 2 samples comprising 4 and 5 individuals respectively; for Th isotopes 1 sample of 54 individuals was split in two; for ${ }^{210} \mathrm{Po}$ and ${ }^{210} \mathrm{~Pb}$ a single sample of 1 individual only was measured. Concentrations factors (C.F.) were calculated assuming the following concentrations in coastal sea water: ${ }^{241} \mathrm{Am}, 2.1 \times 10^{-3} \mathrm{mBq} \mathrm{l}{ }^{-1} \cdot ;{ }^{239+240} \mathrm{Pu}, 38 \times 10^{-3} \mathrm{mBq} l^{-1} \cdot ;{ }^{232} \mathrm{Th}, 74 \times 10^{-3} \mathrm{mBq} l^{-1} \cdot$. ${ }^{210} \mathrm{~Pb}, 1.4 \mathrm{mBq} \mathrm{l}{ }^{-1} \cdots ;{ }^{210} \mathrm{Po}, 1.3 \mathrm{mBq} \mathrm{l}^{-1} \cdots$. Data for thorium isotopes ${ }^{230} \mathrm{Th}$ and ${ }^{228} \mathrm{Th}$ are not given, but all ${ }^{230} \mathrm{Th} /{ }^{232} \mathrm{Th}$ ratios were very close to unity and all ${ }^{228} \mathrm{Th} /{ }^{232} \mathrm{Th}$ ratios were between 1 and 2 . For ${ }^{232} \mathrm{Th},{ }^{210} \mathrm{~Pb}$ and ${ }^{210}$ Po errors are standard deviations of the counting statistics, including propagation of the blank error; for ${ }^{241} \mathrm{Am}$ and ${ }^{239+240} \mathrm{Pu}$ the errors are whichever was the higher of either standard deviations of counting statistics of individual samples or standard deviation between the various samples measured. n.m. $=$ not measured. $1 \mathrm{mBq}=27 \times 10^{-3} \mathrm{pCi}$

\begin{tabular}{|c|c|c|c|c|c|c|c|c|c|c|c|}
\hline & \multirow{2}{*}{$\begin{array}{l}\text { Wet/dry } \\
\text { ratio }\end{array}$} & \multicolumn{5}{|c|}{ Radionuclide concentration ( $\mathrm{mBq} \mathrm{kg}^{-1}$ wet) } & \multicolumn{5}{|c|}{ Concentration Factors (C.F.) } \\
\hline & & ${ }^{241} \mathrm{Am}$ & $239+240 \mathrm{Pu}$ & ${ }^{232} \mathrm{Th}$ & ${ }^{210} \mathrm{~Pb}$ & ${ }^{210} \mathrm{Po}$ & ${ }^{241} \mathrm{Am}$ & $239+240 \mathrm{Pu}$ & ${ }^{232} \mathrm{Th}$ & ${ }^{210} \mathrm{~Pb}$ & ${ }^{210} \mathrm{Po}$ \\
\hline $\begin{array}{l}\text { Branchial } \\
\text { hearts }\end{array}$ & 5.2 & $30 \pm 13$ & $370 \pm 110$ & $560 \pm 70$ & $13700 \pm 700$ & $24000 \pm 1500$ & $1 \times 10^{4}$ & $1 \times 10^{4}$ & $8 \times 10^{3}$ & $1 \times 10^{4}$ & $2 \times 10^{4}$ \\
\hline $\begin{array}{l}\text { Hepatopan- } \\
\text { creas }\end{array}$ & 3.1 & $1.1 \pm 0.7$ & $26 \pm 7$ & $26 \pm 4$ & $32200 \pm 2600$ & $585000 \pm 24000$ & $5 \times 10^{2}$ & $7 \times 10^{2}$ & $4 \times 10^{2}$ & $2 \times 10^{4}$ & $5 \times 10^{5}$ \\
\hline Remainder & 5.9 & $0.3 \pm 0.1$ & $0.3 \pm 0.1$ & $4.4 \pm 0.7$ & n.m. & $3000 \pm 300$ & $1 \times 10^{2}$ & $8 \times 10^{\circ}$ & $6 \times 10^{1}$ & n.m. & $2 \times 10^{3}$ \\
\hline $\begin{array}{l}\text { Reconstituted } \\
\text { animal }\end{array}$ & 5.7 & $0.5 \pm 0.1$ & $2.2 \pm 0.4$ & $6.3 \pm 0.7$ & n.m. & $20000 \pm 700$ & $2 \times 10^{2}$ & $6 \times 10^{1}$ & $9 \times 10^{1}$ & n.m. & $2 \times 10^{4}$ \\
\hline $\begin{array}{l}\text { - Fukai et a } \\
\cdots \text { Cherry an } \\
\cdots \text { Heyraud a }\end{array}$ & $\begin{array}{l}\text { 1. (1976) } \\
\text { d Shanno } \\
\text { and Chen }\end{array}$ & $\begin{array}{l}\text { on (1974) } \\
\text { ry }(1979)\end{array}$ & & & & & & & & & \\
\hline
\end{tabular}


temperate and tropical seas (Wells, 1978). Even though the branchial hearts constitute a small fraction of the cephalopod, the concentrating powers of these organs are such that a mere gram or two (dry weight), which can be obtained from 4 or 5 large individuals, is sufficient to allow the detection of ${ }^{241} \mathrm{Am}$ with an error of about $25 \%$ per sample. The potential of these organs as biological indicators of transuranics and certain natural radioactive elements is to be emphasized. The results of our experiments suggest that they act as a slow-turnover store which might serve as a long-term indicator of exposure. Further, it has been shown recently that the branchial hearts concentrate certain other elements effectively, e. g. vanadium (Miramand and Guary, 1980) and cobalt (Nakahara et al., 1979), with concentration factors of $3 \times 10^{3}$ and $2 \times 10^{4}$ respectively. Interestingly, vanadium and cobalt seem to behave similarly to americium, plutonium and thorium in that they are less concentrated in the hepatopancreas than in the branchial hearts. The branchial hearts are organs with circulatory and excretory functions (Cuénot, 1899; Turchini, 1923; Martin and Harrison, 1966). They are rich in iron (Nardi and Steinberg, 1974) and this metal is localized in intracellular granules composed of purple-brown pigments or adenochromes (Fox and Updegraff, 1943). A recent laboratory experiment (Miramand and Guary, 1981) using autoradiography indicates an association of ${ }^{241} \mathrm{Am}$ with these intracellular granules.

Perhaps we are dealing with a detoxification system comparable to that which has been described for other molluscs (Coombs, 1977; Martoja et al., 1977; Coombs and George, 1978). Many elements accumulated from sea water may be associated with the intracellular granules of the branchial hearts and thus rendered less susceptible to intoxicate the vital organs of the cephalopod. Quite apart from their potential as biological indicators of pollution, the branchial hearts of the octopus are worthy of further study on physiological grounds.

Acknowledgements. The International Laboratory of Marine Radioactivity operates under a tripartite agreement between the International Atomic Energy Agency, the Government of the Principality of Monaco and the Oceanographic Institute at Monaco. The present work was also supported by the Marine Pollution Programme of the South African National Scientific Programmes Unit. We thank S. W. Fowler and A. Walton for critical comments.

\section{LITERATURE CITED}

Cherry, R. D., Shannon, L. V. (1974). The alpha radioactivity of marine organisms. Atom. Energy Rev. 12: 1-45

Coombs, T. L. (1977). Uptake and storage mechanisms of heavy metals in marine organisms. Proc. Analyt. Div. Chem. Soc. 14: 219-222

Coombs, T. L., George, S. G. (1978). Mechanisms of immobilization and detoxication of metals in marine organisms. In McLusky, D. S., Berry, A. J. (eds) Physiology and behaviour of marine organisms. Pergamon Press, Oxford, pp. 179-187

Cuénot, L. (1899). L'excrétion chez les Mollusques. Archs Biol., Paris 16: 49-96

Flynn, W W. (1968). The determination of low levels of polonium-210 in environmental materials. Anal. chim. Actá 43: 221-227

Fowler, S. W., Heyraud, M. Beasley, T. M. (1975). Experimental studies on plutonium kinetics in marine biota. In: Impacts of nuclear releases into the aquatic environment. International Atomic Energy Agency, Vienna, pp. 157-177

Fowler, S. W., Guary, J. C. (1977). High absorption efficiency for ingested plutonium in crabs. Nature, Lond. 266: $827-828$

Fox, D. L., Updegraff, D. M. (1943). Adenochrome, a glandular pigment in the branchial hearts of the octopus. Archs Biochem. 1: 339-356

Fukai, R., Ballestra, S., Holm, E. (1976). ${ }^{241}$ Americium in Mediterranean surface waters. Nature, Lond. 264: $739-740$

Guary, J. C., Fowler, S. W. (1977). Biokinetics of neptunium237 in mussels and shrimp. Mar. Sci. Communs 3: 211-229

Hallden, N. A., Harley, J. H. (1960). An improved alpha counting technique. Analyt. Chem. 32: 1861-1863

Heyraud, M., Cherry, R. D. (1979). Polonium-210 and lead210 in marine food chains. Mar. Biol. 52: 227-236

Higgo, J. J. W., Cherry, R. D., Heyraud, M., Fowler, S. W. (1977). Rapid removal of plutonium from the oceanic surface layer by zooplankton faecal pellets. Nature, Lond. 266: 623-624

Ku, T. L. (1965). An evaluation of the ${ }^{234} \mathrm{U}^{238} \mathrm{U}$ method as a tool for dating pelagic sediments. J. Geophys. Res. 70: $3457-3474$

Martin, A. W., Harrison, F. M. (1966). Excretion. In Wilbur, K. M., Yonge, C. M. (eds) Physiology of mollusca, Vol. II. Academic Press, New York, pp. 353-386

Martoja, M., Lhonoré, J., Elkaim, B. (1977)). Accumulations de métaux et de particules minérales dans les tissus mous de la coque comestible Cerastoderma edule (Mollusque Eulamellibranche). Relation avec le milieu. C. r, hebd. Séanc. Acad. Sci., Paris 284 D: 1453-1456

Millard, H. T. (1963). Quantitative radiochemical procedures for analysis of polonium-210 and lead-210 in minerals. Anal. Chem. 35: 1017-1023

Miramand, P., Guary, J. C. (1980). High concentrations of some heavy metals in tissues of the Mediterranean octopus. Bull. environ. Contam. Toxicol. 24: 783-788

Miramand, P., Guary, J. C. (1981). Association of Americium241 with adenochromes in the branchial hearts of the cephalopod Octopus vulgaris. Mar Ecol. Prog. Ser. 4: $127-129$

Nakahara, M., Koyonagi, T., Ueda, T., Shimizu, C. (1979). Peculiar accumulation of cobalt- 60 by the branchial heart of octopus. Bull. Japan. Soc. scient. Fish. 45:539

Nardi, G., Steinberg, H. (1974). Isolation and distribution of adenochrome(s) in Octopus vulgaris. Comp. Biochem. Physiol. 48 B: 453-461

Noshkin, V. (1972). Ecological aspects of plutonium dissemination in aquatic environments. Health Phys. 22: 537-549

Pillai, K. C., Smith, R. C., Folsom, T. R. (1964). Plutonium in the marine environment. Nature, Lond. 203: 568-571 
Turchini, J. (1923). Contribution à l'étude de l'histologie de la cellule rénale. L'excrétion urinaire chez les Mollusques. Archs Morphol. gén. exp. 18: 7-241

Vilquin, A., Fowler, S. W., Renfro, W. C. (1975). Procedures for radioecological studies with marine benthic invertebrates. In Design of radiotracer experiments in marine biological systems, Techn. Rep. Ser. 167. International Atomic
Energy Agency, Vienna, pp. 107-119

Wells, M. J. (1978). Octopus. Physiology and behaviour of an advanced invertebrate, Chapman \& Hall, London

Wong, K. W. (1971). Radiochemical determinations of plutonium in sea water, sediments and marine organisms. Anal. chim. Acta 56: 355-364 